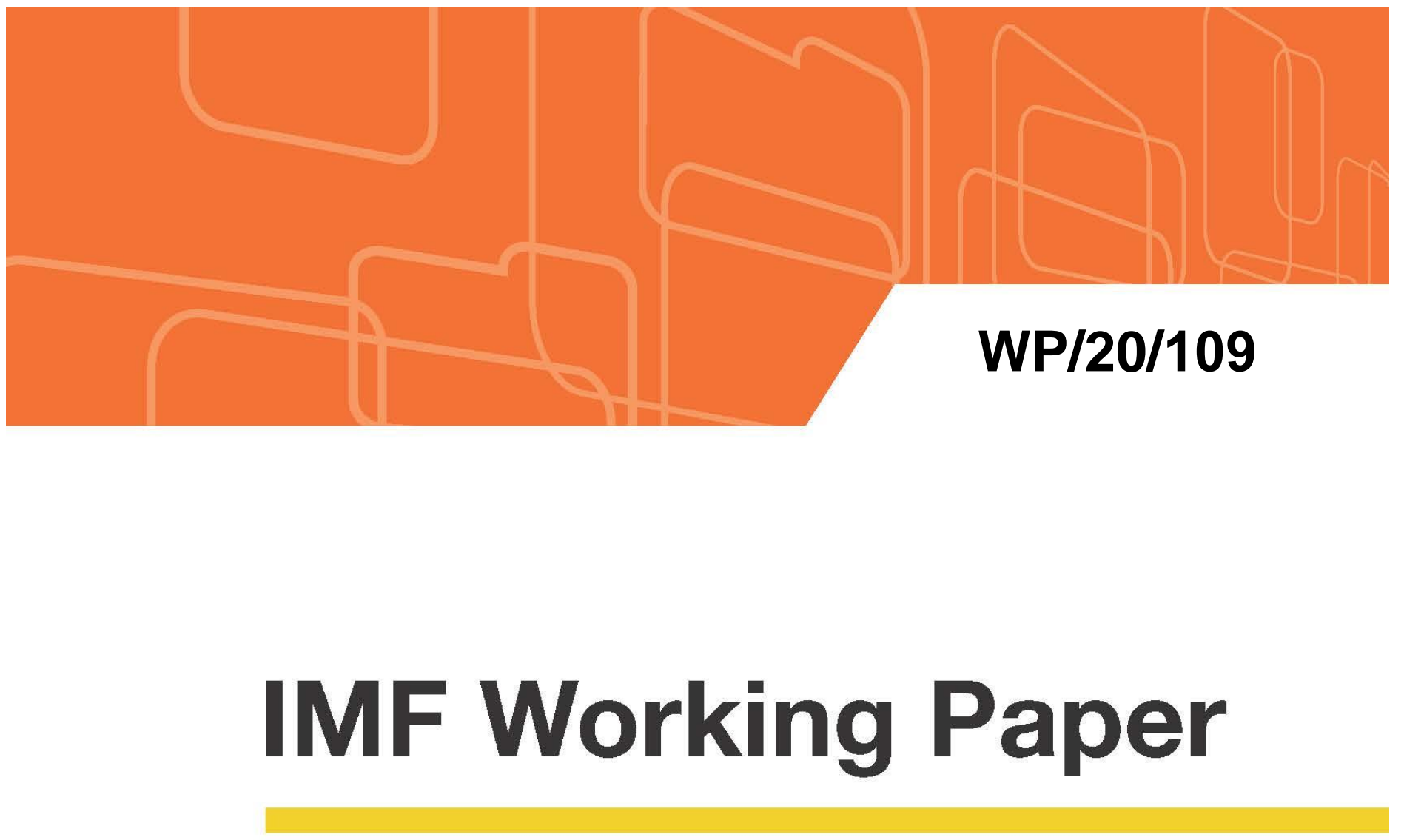

\title{
The Impact of Monetary Policy Communication in an Emerging Economy: The Case of Indonesia
}

by Calixte Ahokpossi, Agnes Isnawangsih, Md. Shah Naoaj, and Ting Yan

IMF Working Papers describe research in progress by the author(s) and are published to elicit comments and to encourage debate. The views expressed in IMF Working Papers are those of the author(s) and do not necessarily represent the views of the IMF, its Executive Board, or IMF management. 
IMF Working Paper

Asia and Pacific Department

\title{
The Impact of Monetary Policy Communication in an Emerging Economy: The Case of Indonesia ${ }^{1}$
}

\author{
Prepared by Calixte Ahokpossi, Agnes Isnawangsih, Md. Shah Naoaj, and Ting Yan \\ Authorized for distribution by Luis E. Breuer
}

June 2020

Disclaimer: This document was prepared before COVID-19 became a global pandemic and resulted in unprecedented economic strains. It, therefore, does not reflect the implications of these developments and related policy priorities. We direct you to the IMF Covid-19 page that includes staff recommendations with regard to the COVID-19 global outbreak.

\section{IMF Working Papers describe research in progress by the author(s) and are published to} elicit comments and to encourage debate. The views expressed in IMF Working Papers are those of the author(s) and do not necessarily represent the views of the IMF, its Executive Board, or IMF management.

\begin{abstract}
Since the adoption of the inflation targeting framework by Bank Indonesia (BI), monetary policy communication has played an increasingly important role in BI's policy toolkit. This paper assesses BI's monetary policy communication from three perspectives: i) its transparency and clarity, ii) its ability to align market expectation and BI's policy decisions (predictability), and iii) its impact on financial markets. In particular, we assess the impact of BI's monetary policy practices by focusing on its monetary policy press releases and monetary policy reports. The results show that Bank Indonesia has made significant progress in the transparency of its communication as well as in the institutional framework to support this. Nonetheless, the results also suggest ways in which the impact of communication can be further improved, including by strengthening the clarity of policy messages, its consistency with the policy framework and the depth of the money market.

JEL Classification Numbers: E3, E44, E52, E58
\end{abstract}

Keywords: Monetary policy; central bank communication; central bank predictability.

Author’s E-Mail Address: cahokpossi@imf.org; aisnawangsih@imf.org; tyan@imf.org; mnaoaj@imf.org

\footnotetext{
${ }^{1}$ The authors are grateful to Luis Breuer, Marco Casiraghi, Hendre Gerber, Chris Papageorgiou, Filiz Unsal, participants at the IMF's Asia Pacific Department seminar and Bank Indonesia's Institute seminar for helpful comments. The authors would also like to thank Key Moriya and Tracey Wanasukaphun for assisting with textual analysis, and Nong Jotikasthira for preparing the paper. The views expressed here are those of the authors and do not necessarily represent the views of the IMF.
} 


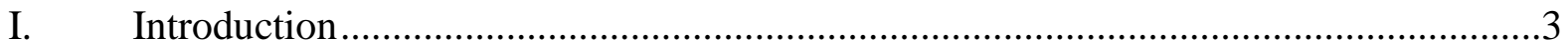

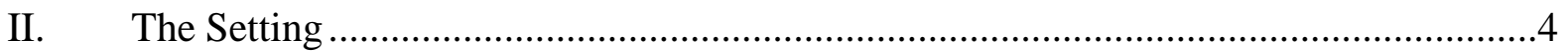

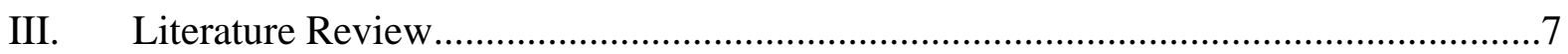

IV. Transparency and Clarity at Bank Indonesia ...................................................

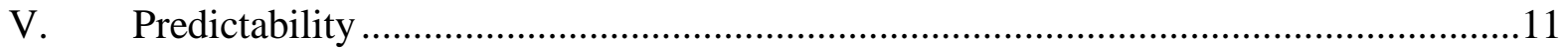

VI. Impact on Fixed-Income Markets and the Exchange Rate ....................................13

VII. Survey on the Impact of Monetary Policy Communication in Indonesia...................16

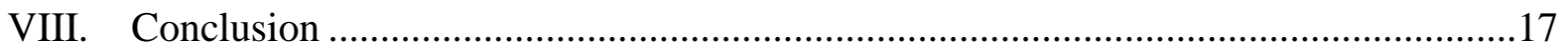

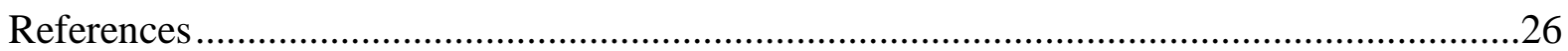

\section{Appendices}

I. Selected Motivations for Monetary Policy Decisions (from Press Releases)..............19

II. Monetary Policy Press Release Readability Scores ...............................................20

III. Predictability of Interest Rate Decision ..........................................................21

IV. Decomposition of Median Surprises and Average Surprises ..................................22

V. Impacts of Monetary Policy Surprises and Publications ........................................23

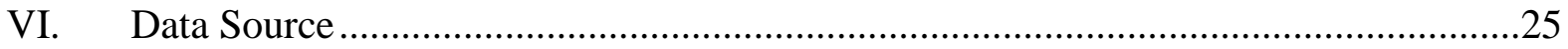




\section{INTRODUCTION}

Communication has become an important tool of monetary policy over the last two decades. Whereas secrecy used to be at the center of central banks' monetary policy actions, transparency and clarity are at premium nowadays, particularly in developed financial markets. Central banks now communicate on their policy objectives, rational for policy decisions, macroeconomic conditions, and forecast of key policy variables, including inflation and output. The communication takes many forms, including press releases, speeches and social media. With this shift, the literature has increasingly focused on assessing the quality and the effectiveness of monetary policy communication. The literature on quality assessment focuses on desirable characteristics of monetary policy that would make it effective, including transparency, clarity and consistency with the overall monetary policy framework. Effectiveness assessment focuses on whether monetary policy communication helps achieve the objectives of monetary policy.

Bank Indonesia (BI) has a robust multi-channel communication strategy targeting different stakeholders, including government, parliament, academics, market participants, general public, media, investors, and rating agencies. In addition, BI uses different tools to assess the impact of its communication.

This paper investigates monetary policy communication in Indonesia for both quality and effectiveness. To do so, the paper analyzes BI's monetary policy communication from three perspectives. First, the transparency and clarity of monetary policy communication, and its consistency with overall monetary policy framework - which are important to align BI and the market's understanding of the drivers of monetary policy decisions. Second, the predictability of monetary policy - with the alignment in understanding in place, monetary policy decisions should be generally predictable for the market. Third, the efficacy of monetary policy - as effective communication can help strengthen the transmission on monetary policy by clarifying policy decisions or providing new information not previously priced in market rates.

The analysis of the impact of monetary policy communication focuses the impact on market rates, as opposed to inflation for many reasons. First, given volatile food prices and administered prices represent $40 \%$ of the CPI, "BI's ability to control inflation is severely constrained during times of major shocks." ${ }^{2}$ Second, BI and the government have established a coordination mechanism to monitor and control inflation, and fiscal and sectoral policies play an important role in controlling inflation in Indonesia. Third, in light of the transmission mechanism of monetary policy to inflation (through the money market rate, then deposit and

\footnotetext{
${ }^{2}$ https://www.bi.go.id/en/moneter/inflasi/bi-dan-inflasi/Contents/Pengendalian.aspx
} 
lending rates), ${ }^{3}$ focusing on the first level of transmission (the money market rate) is appropriate.

The analysis presented below focuses on two tools of monetary policy communication at $\mathrm{BI}$-monetary policy press releases and monetary policy reports. In contrast to other channels of communication, these two channels have been used consistently over a long period of time by BI, thereby providing a suitable time series for robust analysis. Press releases are issued at the end of the regular monthly or extraordinary monetary policy committee meetings. Monetary reports are published on a quarterly basis. For other months of the year, BI issues monetary policy reviews, which are similar to the monetary policy reports, but exclude a forward-looking analysis. In this paper, references to monetary policy reports encompass both monetary policy reports and reviews. The reports are not issued on the same day as the monetary policy press releases, thereby allowing for a separate identification of their impacts.

This paper contributes to the empirical literature on central bank communication by:

(i) focusing on an emerging market economy, as opposed to advanced economies which are extensively covered in the literature, ii) analyzing the structure and content of BI's monetary policy press releases; (iii) providing evidence on the effectiveness of central bank communications in terms of predictability, and (iv) providing evidence on the impact of monetary policy surprise and monetary policy communication on various market rates.

\section{The SeTting}

\section{Bank Indonesia's Monetary Policy Framework}

Monetary policy framework. The independence of Bank Indonesia (BI) from government or other external parties, including for monetary policy, is enshrined in a 1999 law, which was amended in 2004. BI's de jure monetary policy objective is to achieve and maintain the stability of the rupiah value (in terms of prices of goods and services and the exchange rate). To achieve this objective, BI adopted in 2005 a policy strategy consisting of an inflation targeting framework, where inflation is the primary monetary policy objective, while adhering to the free-floating exchange rate system. ${ }^{4}$ In this framework, FX intervention aims to minimize excessive exchange rate volatility, rather than to peg the exchange rate to a particular level. ${ }^{5}$ Medium-term numerical inflation targets are set by the government, in coordination with BI. The operational framework to achieve the inflation target relies mainly

\footnotetext{
${ }^{3}$ https://www.bi.go.id/en/moneter/kerangka-kebijakan/Contents/Default.aspx

${ }^{4}$ The de facto exchange rate system is rather a managed float.

${ }^{5}$ https://www.bi.go.id/en/moneter/tujuan-kebijakan/Contents/Default.aspx
} 
on the BI rate. Other instruments include open market operations on the rupiah and the foreign exchange market, the discount rate and the minimum reserve requirement.

Monetary policy communication approach. With the adoption of the inflation targeting framework, transparency, clarity and consistency of monetary policy has become an important in guiding market expectations. As a result, BI sees communications as an important tool of monetary policy and has developed communication guidelines, regulations and strategy. strategy. These tools are reviewed every month by the Board of Governor. BI's policy messages are prepared and conveyed through a collaborative process involving the Communication Department (CD) and the Economic and Monetary Policy Department (EMPC). The role of CD to select and manage the delivery channels, in line with the broader communication strategy. EMPC focuses on the content of the policy messages. Facing an evolving stakeholder landscape, BI has developed a multi-channel communications strategy targeting different stakeholders, including government, parliament, academics, market, public, media, investors, and rating agencies. These stakeholders are reached through various channels, including press releases, monetary policy report, monetary policy reviews, speeches by senior BI officials, press conferences and outreach.

- Press releases and briefings. Every month, BI holds a two-day monetary policy meeting to evaluate the economy and set the direction of monetary policy. The schedule for policy meetings is usually on Wednesday and Thursday, which is pre-announced on its website. At the end of the monthly meeting, the monetary policy decision is communicated publicly immediately with a press briefing and a press release. Monetary Policy Press Releases are published in Bahasa Indonesia first, followed by same-day publication of English translation to make sure domestic and foreign investors receive the same messages.

- Digital media. Well-adapted to the digital age, BI has been increasingly using nontraditional channels such as social media to reach new audiences. For example, while the monetary policy decision announcement reaches a few dozen journalists present in the room, a bigger audience watch the speech on BI's YouTube livestreaming, and thousands more people watch recorded videos on BI website afterwards.

- Monetary policy reports and reviews. In addition to the press release on the monetary policy decision, BI also publishes a monetary policy report quarterly. The information and analysis in the monetary policy reports contains more detail than in the press releases, including macroeconomic forecasts which are not covered in the monthly press release or monetary policy review.

- Speeches and other forms of communication. Other than press releases, reports and publications, BI's Governor and spokesperson also hold or participate in various communication events related to monetary policy. The Governor does one-on-one interviews with media to reinforce policy messages. BI also holds one-on-one investor 
meetings, monthly meeting with influential economists and quarterly investors meetings jointly with the Ministry of Finance and other government agencies, participates in events proposed by research institutions and universities etc.

- Macroeconomic data and reports. BI also publishes press releases related to various macroeconomic data releases, including GDP, inflation and trade data published by Statistics Indonesia (BPS) or BI's Statistics Department. The Annual Report, which is BI's flagship report, is the Economic Report on Indonesia (LPI). In addition, Recent Economic Development (RED), a monthly communication material in PowerPoint format, has become a guideline for heads of BI's regional and representative offices to communicate with local stakeholders.

Evaluation of monetary policy communication. The Communication Department does a stakeholder evaluation twice a year. Stakeholders in nine large Indonesian cities are surveyed in the first semester, and in 18 cities in the second semester, to map the engagement level and measure the effectiveness of BI's communication with media and analysts. Aside from the evaluation conducted by the Communication Department, the Economic and Monetary Policy Department also conducts a survey on the quality of monetary policy communication. The survey is conducted through questionnares sent to participants of communication events, readers of the published monetary policy reports and investors.

\section{Evolution of Bank Indonesia's Monetary Policy Framework}

In practice, BI's approach to monetary policy has evolved over time. BI now refers to an optimal policy mix, including monetary, macroprudential, payment system and rupiah management policies. ${ }^{6}$ The policy framework also includes considerations for financial stability and maintaining attractiveness to capital inflows to finance the fiscal and current account deficits. ${ }^{7}$ This approach is reflected in the various motivations, beside inflation, that BI's monetary policy press releases have referred to for its policy rate decisions. These motivations include the current account deficit, protection against volatile global markets, and safeguarding the competitiveness of domestic financial markets against changing policies in other countries (see Appendix I for a summary). These motivations create significant challenges in squaring the inflation targeting framework and the optimal policy mix, and may give rise to some confusion for BI's stakeholders.

As noted by Unsal and others (2020), while the medium-term inflation target is still described as the cornerstone of the monetary policy formulation, the explanation of policy decisions and monetary policy reports suggest that the exchange rate and capital flow

\footnotetext{
${ }^{6}$ See BI Monetary Policy Report QIII 2018.

${ }^{7}$ IMF (2019), Box 1.
} 
measures play a key role. However, it is unclear these factors as well as other tools such as FX intervention are taken into account in the decision-making process.

\section{LITERATURE REVIEW}

In the past, it was believed that central banks policy stances should always be masked, and the central bankers should say as little as possible (Blinder and others, 2008). Nowadays, the central bank communication is not cryptic anymore, especially for developed financial systems as they regularly communicate their macroeconomic conditions, policy frameworks, objectives, forecasts on inflation and output, and motivations for policy decisions (Tobias and others, 2018). After the global financial crisis (GFC) and its aftermath, central bank communication, in particular forward guidance, became even more important for the sake of financial sector stability. As a result, many central banks (both developed and developing) are now focusing more on their communication policy.

Nowadays, accountability, transparency and managing private sector expectations are key for an independent central bank, and communication is a crucial tool for achieving these goals (Blinder and others, 2008). Central banks transparency augments policy credibility, policy flexibility, policy predictability and enables markets to respond more smoothly in response to policy decisions. If an independent central bank communicates its economic outlook and policy stances more transparently, the stakeholders are less likely surprised by the monetary policy decisions which causes smooth movements in asset prices and reduces the likelihood of financial distress (Pescatori, 2018).

Dincer and Eichengreen $(2007,2014)$ proposed a widely used index to measure central bank transparency. The Dincer-Eichengreen transparency index is constructed from the assessment of 15 dimensions of central bank transparency, including whether there is (i) a formal statement of monetary policy objective(s) with explicit prioritization of objectives when there are multiple objectives, (ii) a quantification of the primary objective(s), (iii) the independence of the central bank vis-à-vis the government, and (iv) the public provision of data relevant for the conduct of monetary policy. The index covers five broad transparency areas: political, economic, procedural, policy and operational.

Unsal and others (2020) proposes a comprehensive toolkit to assess the quality of monetary policy frameworks. The toolkit provides a granular and multi-dimensional evaluation of monetary policy frameworks, covering the following four dimensions: Foundations (covering the independence and accountability framework), Policy Strategy, Operational framework and Communication Strategy. The authors use this granular evaluation to build an overall index of monetary policy frameworks covering all the dimensions of the toolkit. In contrast to previous toolkits, this one assesses both de jure and de facto frameworks in terms of the transparency and consistency of the different dimensions of monetary policy frameworks. 
To understand the effectiveness of monetary policy communications, a number of empirical studies have been done in recent past. Empirical analysis shows that the predictability of the interest rate decisions of major central banks has improved remarkably in recent years so that financial markets' expectations nowadays are generally well aligned with actual policy decisions (Bernoth and von Hagen, 2004). Blinder and others (2008) find that frequent and better central bank communications improve predictability of monetary policy, and contributes to reduce the noise of monetary policy transmission, whereas the predictability is somewhat weak when central bank communicates self-contradictory messages. The case of the U.S. Federal Reserve, with its continuously increasing level of transparency since the 1980s, has been studied most extensively. Poole and Robert Rasche (2003) provide evidence that the surprise component of monetary policy decisions decreased substantially in U.S. after 1994. Swanson (2006) analyzes the predictability of U.S. federal funds rate and finds that the financial markets and private sector forecasters can better predict the fund rate up to several-month horizons. In terms of predictability and transparency, Federal Reserve's decision to make policy announcement at specific meeting dates reduces the uncertainty of policy decision, and market can better anticipate the timing and nature of policy moveswhich enables Fed to move actual funds rate with smaller open market operations (Demiralp and Jorda, 2002).

Recently, a large number of studies investigated the effect of monetary policy on short- and long-term interest rates. The theoretical literature assumes that monetary policy has impact on short term interest rates movement while long-term interest rates and other asset prices are channeled through expectations (Blinder, 1998). In this regard, central bank's communications play a significant role to shapes the stakeholder's expectations. Kohn and Sack (2004) sheds light on transmissions of monetary policy statements through short-term interest rate and assets valuations in the United States. They find that, the statements of Fed chairman Greenspan and Federal Open Market Committee (FOMC) significantly affect the short-term interest rate and the statement on asset valuation has a less significant effect. Gürkaynak and others (2005) show that rates at long horizons react significantly to macroeconomic and monetary policy surprises that are typically expected to have only transitory effects on short-term interest rates.

Many cross-country studies assess the effectiveness of monetary policy communication under different strategies. Connolly and Kohler (2004) conducted a study on central bank communication and interest rate expectations for six developed countries - Australia, Canada, the Euro area, New Zealand, the United Kingdom, and the United States. They find that both macroeconomic news and policy news significantly affect interest rate expectations for these six countries.

While many studies have assessed the effectiveness of central bank communication in developed economies, only a few have done so for emerging markets. Rozkrut and others (2007) finds that the central bank communication strategies differ significantly in Hungary, Poland and Czech Republic, and the effectiveness of communication in terms of policy 
predictability for these three countries depends on the monetary policy structure and communication strategy. McMahon and others (2018) find that China's central banks communications mainly affects short-term asset prices, at least in a single days' timeframe, while neither monetary policy instruments nor communication systematically move longer-term markets much.

IMF (2018) finds that stronger transparency frameworks and communication strategies are associated with more predictable policy decisions and a better anchoring of inflation expectations in Latin America. Pescatori (2018) examines the central bank communication effectiveness and monetary policy predictability in Chile. He finds that the central bank's policy actions are predictable and impacts of policy rates surprises on capital market index and exchange rate are not robust even though they have the right sign. Our estimation approaches are similar to the ones used in this paper.

\section{TRANSPARENCY AND Clarity AT BANK INDONESIA}

\section{Drawing from the Literature}

Transparency is a key element of accountability and a way of enabling markets to respond more smoothly to policy decisions. Transparency provides the public with a better understanding of the central bank's objective and the factors that motivate monetary policy decisions (Dincer and Eichengreen, 2014). The DincerEichengreen transparency index suggests that BI's monetary policy transparency has improved substantially over the last two decades. BI's monetary policy transparency now ranks among the highest for emerging markets. Most of the improvement occurred ahead of the adoption by $\mathrm{BI}$ of the inflation targeting framework in 2005.

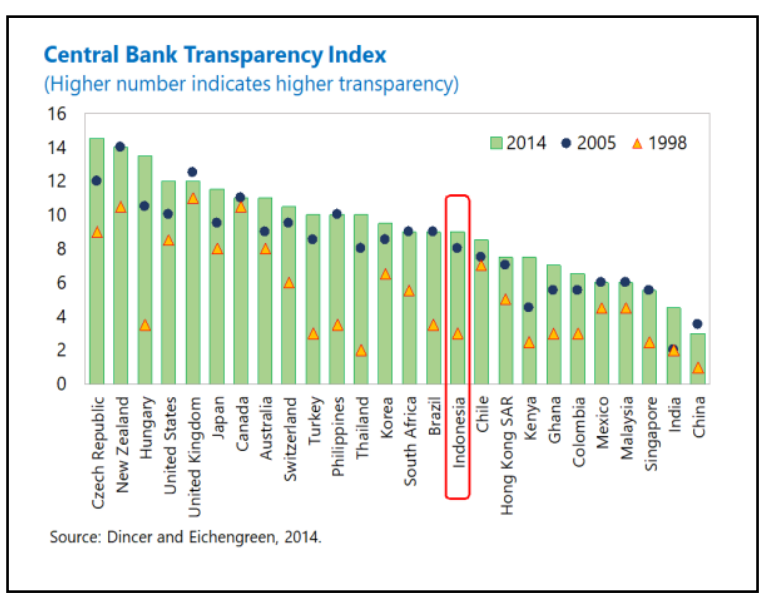

The comprehensive index of monetary policy frameworks proposed by Unsal and others (2020), also indicates that the transparency of BI's monetary policy framework is high and among the highest for emerging markets. However, the authors note that the overall score for BI has declined after 2013, and in particular between 2016 and 2018. They explain the decline by the fact that "BI has moved towards an explicit acknowledgement of entirely integrated use ("optimal mix") of financial stability, exchange rate, and capital flow policies in its communication while keeping the Policy Strategy and Operational Framework the same." In other words, the de facto framework is not entirely consistent with the de jure one. 
This observation is consistent with our early analysis of the de facto framework and the related challenges for monetary policy communication (Appendix I).

\section{Clarity of BI's Monetary Policy Decisions Press Release}

Transparency alone is not enough to understand monetary policy decisions and directions. The literature suggests that clarity of monetary policy message is also necessary, as the provision of too much information can complicate messaging. Hernandez-Murillo and Shell (2014) found that more information provided about policy decision has increased the complexity of FOMC post meeting statements. Blinder (2008) suggests that clearer communications have higher signal-to-noise ratios and should thus provide more useful information. Fracasso and others (2003) found that clarity of presentation and consistency over time are crucial. They suggested that excessive length should be avoided, because it puts off readers and it almost invariably leads to a dilution of the information content. Using the Flesch-Kincaid index of readability, Bulir, Cihak, and Jansen (2014) measured the clarity of inflation reports by four central banks before and during the GFC and found an association of clarity and reduced market volatility. The Flesch-Kincaid ${ }^{8}$ measure of readability suggests, among other things, that longer sentences (and complicated words with many syllables) reduce the clarity of messages.

To assess the clarity of BI's message, we analyze the structure of BI's monetary policy statements (press releases) written in both Indonesian language (Bahasa Indonesia) and English.

During 2006-2018 there were 158 press releases in Indonesian and 156 in English available from the BI website. Based on the number of downloads, the Indonesian versions of the press release appear more popular among readers, presumably reflecting the large domestic audience.

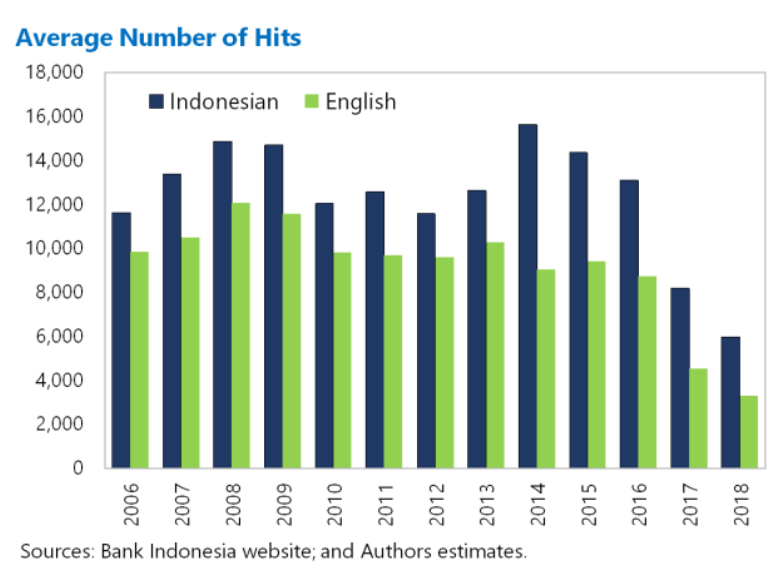

Sources: Bank Indonesia website; and Authors estimates

Downloads were higher around the GFC and the Taper Tantrum (TT) periods.

Our analysis finds that the length of monetary policy press releases (the number of words) has increased over time, reflecting an increase in both the number and the length of paragraphs. As each paragraph typically covers a different issue, this suggests that BI has included more information over time. Therefore, the length of the press releases is not an issue in itself, as the press releases could be providing more relevant information. However,

\footnotetext{
${ }^{8}$ Flesch-Kincaid Index on 0-100 scale is based on this formula: 206.835 - $1.015 \mathrm{x}$ (words/sentences) - $84.6 \mathrm{x}$ (syllables/words). Low scores indicate text that is complicated to understand. For most business writing, a score of 65 is a good target.
} 
as noted above, the literature suggests that long sentences weaken readability. In this respect, our analysis of BI's press releases finds that paragraphs and sentences have become longer, suggesting that clarity may have weakened over time. The results are broadly similar whether the Indonesian or English version of the press releases are analyzed.
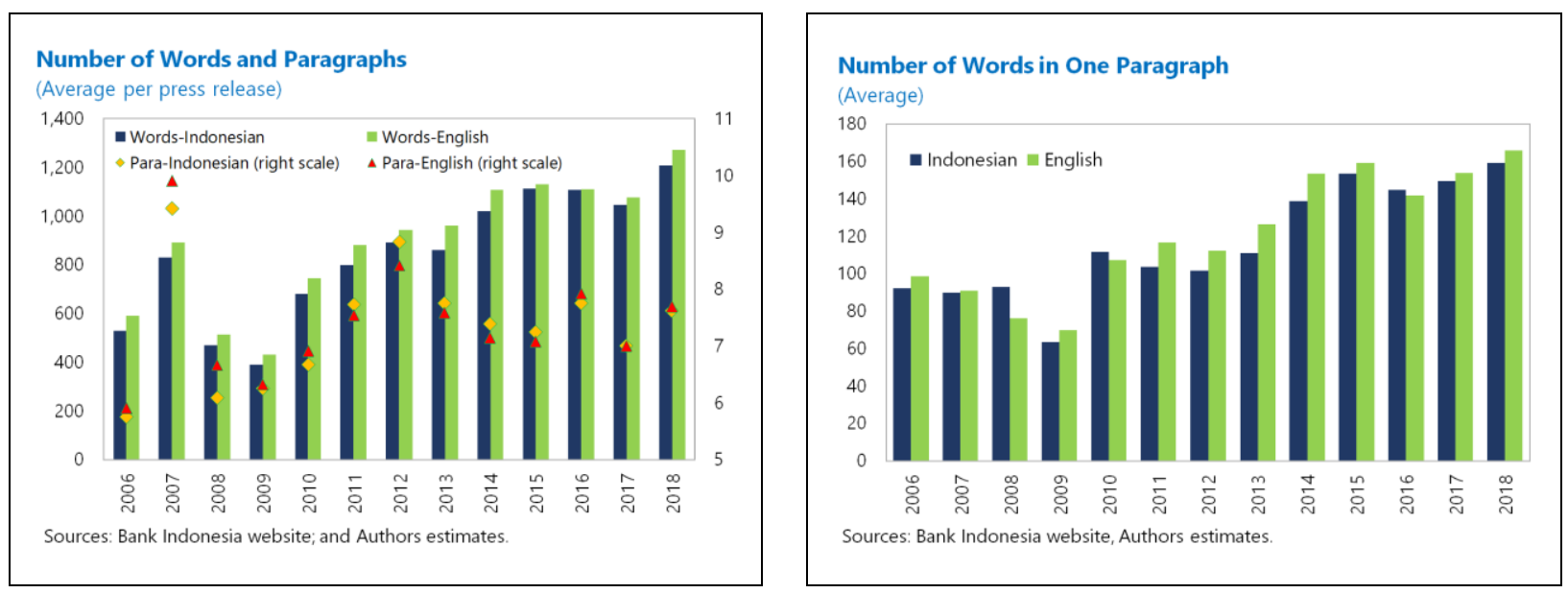

In addition, various readability indices suggest that the English version of BI's monetary policy press releases texts are relatively complicated (Appendix II). ${ }^{9}$ The FleschKincaid scores were lower than the suggested good business writing score of 65 . Lower scores indicate more complicated to understand the text. The Gunning Fog index ${ }^{10}$ suggest that BI press releases were written in long sentences using complicated language. The scores are above 12, which suggest that the texts are too difficult for most people to

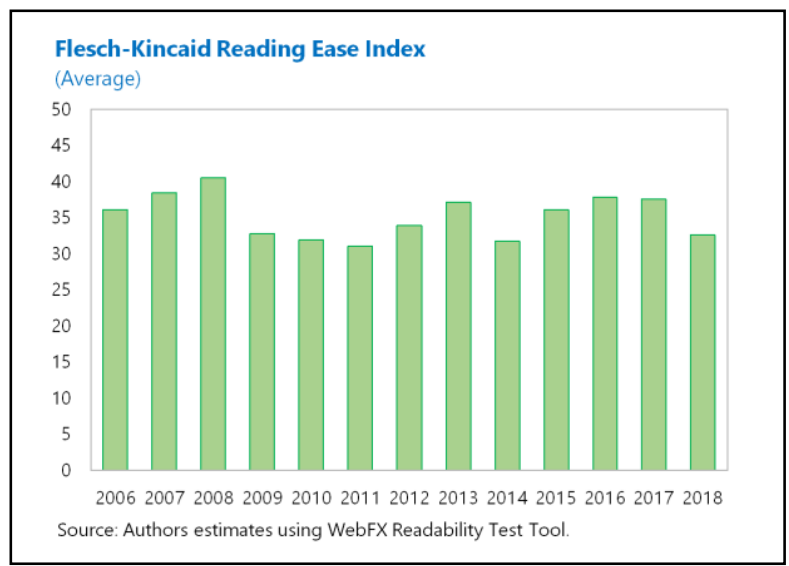
comprehend, requiring at least eleven years of education to comprehend.

\section{Predictability}

Transparency of monetary policy framework and clarity of message help guide market expectations of interest rate and improves the predictability of monetary policy. A lasting impact on interest rate expectations also requires consistency between words and deeds, and

\footnotetext{
${ }^{9}$ The readability indices have not been developed for Bahasa Indonesia yet.

${ }^{10}$ Estimates the years of formal education needed to comprehend a passage of text on the first reading. Grade level $=0.4(\mathrm{ASL}+\mathrm{PHW})$, where ASL $=$ average sentence length and PHW $=$ percent complex words. Complex words are words that contain three or more syllables that are not proper nouns, combinations of easy or hyphenated words, or two-syllable verbs made into three by adding -es and -ed endings.
} 
a track record of monetary policy decisions that supports the central bank's credibility (Blattner and others, 2008). In this section, we assess the predictability of monetary policy in Indonesia by comparing market expectations to actual BI decisions.

Bloomberg conducts a survey of analysts covering Indonesia, within the 24 hours prior to BI's monetary policy meetings. The difference between BI's rate decision $\left(i_{t}\right)$ and analysts' anticipated rate $\left(\mathrm{E}_{\mathrm{t}-1} \mathrm{i}_{\mathrm{t}}\right)$ constitutes a monetary policy surprise (unanticipated monetary policy change). The change in policy rate by $\mathrm{BI}\left(\Delta \mathrm{i}_{\mathrm{t}}\right)$ can therefore be broken down into unanticipated policy change $\left(\Delta i_{j, t}^{u}\right)$ or monetary policy surprises and anticipated policy change $\left(\Delta i_{j, t}^{a}\right)$.

$$
\Delta i_{t}=\left(i_{t}-i_{t-1}\right)=\left(i_{t}-E_{t-1} i_{t}\right)+\left(E_{t-1} i_{t}-i_{t}\right)=\Delta i_{j, t}^{u}+\Delta i_{j, t}^{a}
$$

Where " $\mathrm{i}$ " is the policy rate; " $\mathrm{t}$ " is the time index; " $\mathrm{E}_{\mathrm{t}-1 \mathrm{i} \mathrm{t}}$ " is the market expectation at time " $t-1$ " of the policy rate at time $t$.

Between 2006 and 2018, monetary policy rate fluctuated between 4.25 percent and 12.75 percent (Appendix III). The policy rate essentially declined over the period, as inflation declined from over 13 percent in 2006 to around 3.0-4.0 percent in recent years. Between 2006 and 2018, there was a total of 158 monetary policy committee meetings, and monetary policy rate changed on 53 occasions (one meeting out of three on average), with the number of interest cuts about twice the number of hikes (34 cuts versus 19 hikes).

Overall, monetary policy is somewhat predictable as shown by forecast errors in Bloomberg analysts surveys. The median forecaster has been surprised 30 times out of 158 meetings (i.e., 19 percent of the time or about one every five meetings). Surprises were relatively less frequent when rates were unchanged i.e., surprises conditional on no policy change (five times out of 105 occasions of unchanged rates or about 5 percent of the time) _ suggesting that the BI is more likely to surprise markets and operators when it moves the policy rate. Surprises were relatively frequent for rate hikes (12 times out of 19 rate hikes or about 63 percent of the time) and moderate for rate cuts (13 times out of 34 rate cuts or about 38 percent of the time).

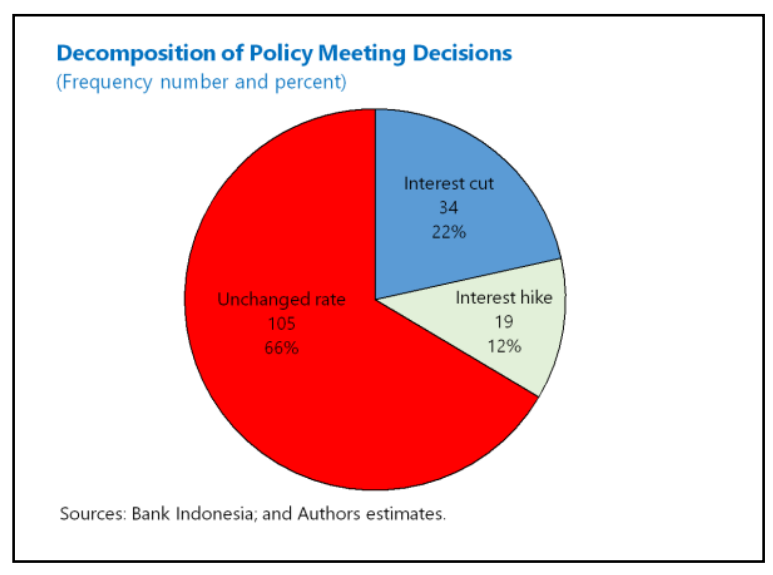

The median surprise (Appendix IV), however, masks some forecast disagreements that could be picked up by looking at averages. As long there is at least one forecast error in the sample, the average is non-zero. In our sample, the average forecaster has been surprised 88 times out of 158 meetings (i.e., about 56 percent of the time or about one every two meetings). Unlike 
median foreast, surprises were relativley more frequent when rates were unchanged (39 times out of 105 occasions of unchanged rates or about 37 percent of the time). However, the average forecaster has been surprised almost whenever the BI changes the policy rate (i.e, 95 percent of the time for rate hikes and 91 percent of the time for rate cuts).

Compared to other emerging markets, the forecast error by the median analyst is relatively frequent relative. In particular, in periods of market stress, the frequency of error is higher. Even though forecast errors, measured by the mean square forecast error of BI policy decision, are relatively frequent, their size is relatively small compared to other emerging markets (Appendix III).

\section{IMPACT ON FIXED-INCOME MARKETS AND THE EXCHANGE RATE}

We assess the impact of monetary policy communication on fixed-income markets and the exchange rate from different perspectives. The analyses below are based on the median forecasting error. The average forecasting error is used as robustness check. The median forecasting error gives a better sense of the distribution of the forecasters and where most of them stand. In that sense, if the median forecaster is surprised by BI's rate decision (median forecast error is none zero), that means that at least half of the forecasters have been surprised. Conversely, if the median forecaster is not surprised (median forecast error is zero), then at least half of the forecasters have not been surprised. In contrast, the average forecasting error is always none zero, as long as one forecaster is surprised.

\section{Market Reaction to Monetary Policy Surprises}

When the market correctly anticipates monetary policy decision, market rates should reflect that anticipation. As a result, policy decisions that are in line with market expectations would not have a significant impact on market rates. In contrast, unanticipated decisions (surprises) should have a significant impact on market rates. We test this understanding against money market rates, bond yields and the exchange rate by running an ordinary least square with robust standard errors. The dependent variables are market rates, the independent variables are anticipated and unanticipated rate changes in policy rates, and the control variables include global factors (changes in U.S. Fed rates, 1-month money market rate, and 10-year government bond yield), and country risk (EMBI and CDS for Indonesia). ${ }^{11}$

$$
\Delta m_{t}=\alpha_{0}+\alpha_{u} \Delta i_{j, t}^{u}+\alpha_{a} \Delta i_{j, t}^{a}+\alpha_{c} \text { Controls }+\varepsilon_{t}(2)
$$

The results show that monetary policy surprises have a significant impact on money market rates, but there is no evidence that they affect the bond market (Appendix V, Table V.1). As expected, anticipated monetary policy decisions have no significant impact on market rates,

\footnotetext{
${ }^{11}$ See Appendix VI for data sources.
} 
while decision surprises have a significant impact on money market rates, with the impact declining along the maturity curve. The results show that a $100 \mathrm{bps}$ surprise increases the overnight interbank rate by $137 \mathrm{bps},{ }^{12}$ and the impacts fades along the money market yield curve to $54 \mathrm{bps}$ for the 1-month rate. In contrast, rate surprises do not have a significant impact on bond yields and the exchange rate, very likely because of shallow financial markets, including an incomplete yield curve. ${ }^{13}$ This suggests that it is important to undertake key financial deepening reforms, include by improving liquidity and activity in the money market beyond one month of maturity and increasing the issuance of short-term government securities.

Notwithstanding remaining challenges in the money market, BI and the government have undertaken measures to improve the functioning of this market in recent years. ${ }^{14}$ In 2018 , they launched the National Strategy on Financial Market Development (2018-2024), highlighting financial deepening as one of the policy priorities. BI issued several regulations and guidelines, including on negotiable certificate of deposits for banks, commercial papers for nonbank corporations, and interest rate derivatives for both, to help them diversify funding sources and facilitate risk sharing and longer-term financing. In August 2018, BI started publishing a transaction-based Indonesia Overnight Index Average (IndONIA) to replace the quotation-based overnight JIBOR as the overnight money market benchmark rate.

\section{Isolating the Impact of Press Release on Market Rates}

Beyond the rate decision, the monetary policy press release can convey additional information that move market rates, at short, medium and long horizons. Such information could be in the form of forward guidance, or highlight of risks not accounted for by the market. We test this hypothesis by exploring whether in the absence of policy rate surprises there is still a significant impact of press releases on market rates. The identification approach here relies on the fact that on days when there is no monetary policy surprise, there should be no significant shift in market rates. If such shift is observed, it could be attributed to the content of the press release (not to the policy rate decision), provided other key drivers of market rates are accounted for. While a random event can occasionally move particular maturities or the entire yield curve, a consistent and significant shift in the curve on days when the press release is issued (and there is no rate surprise) could be reasonably attributed to the content of the press release. In other words, it is unlikely that other factors, say a change in reserve requirement, would consistently co-occur with press releases of monetary

\footnotetext{
${ }^{12}$ The fact that the reaction of the overnight rate to surprises is higher than 100 is unexpected. This could reflect some market imperfections or that market anticipations that did not fully affect the overnight rate until after the decision is announced.

${ }^{13}$ Other aspects of the shallow financial markets in Indonesia include the money market, which is active only for maturities up to one month, the lack of government securities for maturities of one year or less.

${ }^{14}$ See IMF (2019) Box 3 for more details.
} 
policy rate decisions. To capture the impact of the content of the press releases, we interact the short-end of the money market (overnight rate) with a dummy variable indicating whether there was a policy rate surprise or not (see equation 3). Given the interaction term in this equation, the coefficient of the "overnight" rate captures the effect of the press release in the absence of a surprise (surprise dummy is zero).

$$
\begin{gathered}
\Delta m_{t}=\alpha_{0}+\text { overnight }+ \text { surprise }+ \text { overnight } * \text { surprise }+\alpha_{u} \Delta i_{j, t}^{u}+\alpha_{a} \Delta i_{j, t}^{a} \\
+\alpha_{c} \text { Controls }+\varepsilon_{t}(3)
\end{gathered}
$$

Where "overnight" is the overnight money market rate and "surprise" is the dummy variable which takes the value 1 if there is a monetary policy rate surprise (i.e., the median forecast error is none zero), and zero overwise.

The results indicate that press releases do not have a signficant impact on market rates beyond the impact of the policy rate decision itself (Appendix V, Table V.2). While there is a significant impact of policy rate changes on the short-end money market maturity curve, it does not propagate along the entire curve. In addition, there is no significant impact on bond yields and the exchange rate.

\section{Impact of Monetary Policy Reports on Market Rates}

To measure the impact of monetary policy reports on market rates, we consider whether there is a significant shift in the yield curve on the days of release of the reports (restricted sample) as compared to other days (full sample). We measure the shift by estimating whether a movement in the short-end of the yield curve (overnight interbank rate) significantly propagates to all maturities along the yield curve (coefficient $\alpha_{1}$ of equation 4 ). The identification approach here relies on the fact that if on days when a monetary policy report (MPR) is released, there is significant shift in market rates relative to other days (the entire sample covers all days between 2005 and 2018), such a shift it could be attributed to the content of the monetary policy reports, provided other key drivers of market rates are accounted for. The coefficient $\alpha_{2}$ of equation 4 captures the MPR-specific effect. Equation (4) below summarizes our approach, for a given maturity $m$ :

$$
\begin{gathered}
\Delta m_{t}=\alpha_{r, 0}+\alpha_{1} \text { overnight }+\alpha_{2} M P R_{-} D+\alpha_{3} \text { overnight } * \text { MPR_D }+\alpha_{4} \text { Controls } \\
+\varepsilon_{t}(4)
\end{gathered}
$$

Where "overnight" is the overnight money market rate, "MPR_D" is a dummy variable for days when a MPR was released, and "controls" are same control variables used in equation 1.

The results indicate that monetary policy reports do not have a significant impact on market rates (Appendix V, Table V.3). 


\section{Impact of Monetary Policy Press Release (PR) and Monetary Policy Reports (MPR) on Market Rates (full sample)—Robustness check}

Here we focus on the impact of PR and MPR on market rate, irrespective of the direction of the impact. In the full sample, we estimate the impacts by regressing the absolute value of market rate changes on dummy variables capturing whether a PR or MPR was release on a given day, while controlling of other factors that could affect market rates.

$$
\left|\Delta m_{t}\right|=\alpha+\beta_{1} D(M P)_{t}+\beta_{2} D(M P R)_{t}+\beta_{3} D(\text { Macro })_{t}+\beta_{4} \Delta i_{t}+\beta_{5} \text { Controls }+\varepsilon_{t}(6)
$$

Where $\left|\Delta m_{t}\right|=$ absolute value of change in market rates; $\mathrm{D}(\mathrm{MP})=$ press release dummy; $\mathrm{D}(\mathrm{MPR})=$ monetary policy report dummy; $\mathrm{D}($ Macro $)=$ macroeconomic release dummy (covering the release of data on growth, inflation, trade); $\Delta i_{t}=$ change in policy rate.

The results confirm that monetary policy press releases and monetary policy reports have no significant impact on market rates (Appendix V, Table V.4).

Even though press releases and monetary policy reports have no significant independent impact on market rates, they might be useful in other ways not assessed here. For example, over time, they may provide more clarity on the policy framework without affecting market rates contemporenously. In addition, BI is constantly upgrading its communication tools. For example, in February 2020, BI published a new version of its Monetary Policy Report. The new report is more concise, and the outlook section puts more emphasis on the assumptions underlying the outlook. This, along with other changes could improve the impact of the MPR going forward.

\section{SURVEY ON THE IMPACT OF MONETARY POLICY COMMUNICATION IN INDONESIA}

The authors conducted a survey on the impact of monetary policy communication in mid-2019. The survey covered issues related to monetary policy objectives, clarity and transparency of BI monetary policy decision communications, predictability of BI monetary policies, and the efficacy of monetary policy communications. It was sent to 83 Indonesia-based and international journalists and analysts and 18 responses in total were received.

While the number of responses did not yield a representative sample to reach robust conclusions, they came from Indonesia-based respondents, who have been BI watchers for more than five years on average, including 12 analysts/economists and 6 journalists. Given that these respondents work closely with BI, they might be inclined to be more supportive of $\mathrm{BI}$ or have access to useful information channels beyond those analyzed in this paper. With these potential limitations in mind, the key takeaways from the respondents include:

- BI's monetary policy press releases have referred to various motivations beside inflation for its policy rate decisions, which may create some confusion among BI's stakeholders. 
The survey also shows that more than half of survey respondents noted that BI's policy objectives change sometimes, but overall most respondents consider BI's monetary policy objectives as clear.

- While our analysis finds that the length of monetary policy press releases has increased over time and paragraphs and sentences have become longer, few respondents think they are "somewhat long." Most respondents think the length of BI press releases are "just right" and overall BI's policy releases are clear. Almost all agree that BI has improved the clarity of press releases over time.

- While press releases and monetary policy reports have no statistically significant impact on market rates, they might be useful in other ways not assessed here. This is also acknowledged in the survey results, where more than 80 percent of the respondents regard the information in the MPRs as important.

\section{CONCLUSION}

This paper shed some light on the transparency, clarity, predictability, and impact of monetary policy communication on financial markets in Indonesia by focusing on two channels of communication - monetary policy press releases and reports.

On the one hand, the results point to some encouraging aspects of monetary policy communication in Indonesia: i) the monetary policy transparency has improved over time, in particular in the period leading to the adoption by BI of the inflation targeting framework in 2005, and now ranks among the highest for emerging markets; and ii) compared to peers, the gap between market expectations and actual monetary policy decisions by BI is relatively small, suggesting that the policy framework and communication help make monetary policy more predictable. On the other hand, the results point to ways in which the impact of monetary policy communication can be improved: i) the clarity of monetary policy communication appears to have weakened, due to long sentences and complex wording structures that characterize monetary policy press releases; ii) monetary policy surprises have a significant impact on money market rates up to maturities of one month, but no significant impact on the bond market and the exchange rate. This reflects to some extent the fact that the yield curve is incomplete in Indonesia; and iii) controlling for monetary policy decisions, monetary policy press releases and monetary policy reports itself do not have a significant impact on market rates. A limited survey of observers of BI's monetary policy supports these nuanced results, though the survey results are more supportive of progress in monetary policy communication by BI.

Together, the results suggest that, building on progress made over the last two decades, some policy adjustments would help further strengthen the quality and impact of BI's monetary policy communication. First, BI could improve the clarity of its monetary policy communication, while maintaining its provision of relevant information for stakeholders 
(transparency), by look for ways to making its press releases more concise and its language simpler. Second, it would be useful to deepen financial markets including by improving liquidity and activity in the money market beyond one month of maturity and increasing the issuance of short-term government securities. This will help improve the transmission of monetary policy, including the transmission of monetary policy communication to financial markets. Efforts are underway at BI to tackle these challenges.

Monetary policy does not operate in vacuum. It interacts with other policies, in particular fiscal and macroprudential ones. In this respect, monetary policy decisions, at times, take into account other policies. That is why further public disclosure of BI's optimal policy mix, including how the monetary policy framework interacts with other policies, will be useful. 


\section{ApPendix I. Selected Motivations for Monetary Policy Decisions (FROM PRESS RELEASES)}

\begin{tabular}{|c|c|c|c|c|}
\hline & Date & Tightening & Loosening & Motivation for rate change \\
\hline \multirow{6}{*}{$\begin{array}{l}\text { Global Food and } \\
\text { Fuel Crisis }\end{array}$} & $5 / 6 / 2008$ & 1 & & Inflation (international commodity prices and domestic non-food consumption) \\
\hline & $6 / 5 / 2008$ & 1 & & Inflation (world food and energy prices and domestic demand) \\
\hline & $7 / 3 / 2008$ & 1 & & Inflation (fuel, food, and other goods) \\
\hline & $8 / 5 / 2008$ & 1 & & Macro stability (economy, financial, and inflation) \\
\hline & $9 / 4 / 2008$ & 1 & & Macro stability (current and outlook global evironment, inflation) \\
\hline & $10 / 7 / 2008$ & 1 & & Macro stability (changing in global evironment, inflation) \\
\hline \multirow{5}{*}{$\begin{array}{l}\text { Taper Tantrum } \\
\text { (tightening) }\end{array}$} & $6 / 13 / 2013$ & 1 & & Inflation, macro and financial stability \\
\hline & $7 / 11 / 2013$ & 1 & & Inflation (after fuel price increase) \\
\hline & $8 / 29 / 2013$ & 1 & & Inflation expectation, external conditions \\
\hline & $9 / 12 / 2013$ & 1 & & Inflation, external (exchange rate stability) \\
\hline & $11 / 12 / 2013$ & 1 & & External (current account deficit and global uncertainty) \\
\hline \multirow{4}{*}{ Loosening } & $1 / 14 / 2016$ & & 1 & Stable macro (inflation), external (easing uncertainty of global financial markets) \\
\hline & $2 / 18 / 2016$ & & 1 & Stable macro (inflation), external (easing uncertainty of global financial markets) \\
\hline & $3 / 17 / 2016$ & & 1 & Stable macro (inflation), external (easing uncertainty of global financial markets) \\
\hline & $6 / 16 / 2016$ & & 1 & Low inflation, external (controlled current account and stable exchange rate) \\
\hline \multirow{10}{*}{$\begin{array}{c}2018 \text { EM Pressure } \\
\text { (tightening) }\end{array}$} & $5 / 17 / 2018$ & 1 & & Macro stability, External (tightening global conditions) \\
\hline & & & & External (pre-emptive, front-loaded policy) for exchange rate stability, against \\
\hline & $5 / 30 / 2018$ & 1 & & volatile global markets. \\
\hline & & & & External (safeguarding competitiveness of domestic financial market against \\
\hline & $6 / 29 / 2018$ & 1 & & changing monetary policies in other countries) \\
\hline & & & & External (safeguarding competitiveness of domestic financial market against \\
\hline & $8 / 15 / 2018$ & 1 & & changing monetary policies in other countries) \\
\hline & & & & External (reduce the current account deficit and maintain attractiveness of \\
\hline & $9 / 27 / 2018$ & 1 & & domestic financial market) \\
\hline & $11 / 15 / 2018$ & 1 & & External (reduce the current account deficit) \\
\hline
\end{tabular}


Appendix II. Monetary Policy Press Release Readability Scores

\begin{tabular}{cccc}
\multicolumn{5}{c}{ Bank Indonesia's Monetary Policy Press Releases Readability Scores } \\
(Average)
\end{tabular}

Source: Authors estimates using WebFX Readability Test Tool.

1/ Flesch-Kincaid Index on 0-100 scale is based on this formula: $206.835-1.015 \mathrm{x}$ (words/sentences) $-84.6 \mathrm{x}$ (syllables/words). Low scores indicate text that is complicated to understand.

2/ Measures school grade level needed to comprehend the material using formula: $0.39 \times$ (words/sentences) $+11.8 \times$ (syllables/words) -15.59 .

3 / Grade level $=0.4^{*}$ (words/sentences + percent complex words). Complex words are words that contain three or more syllables that are not proper nouns, combinations of easy or hyphenated words, or two-syllable verbs made into three by adding -es and ed endings. Anything above 12 is too hard for most people to read. 


\section{ApPendix III. Predictability OF Interest Rate Decision}
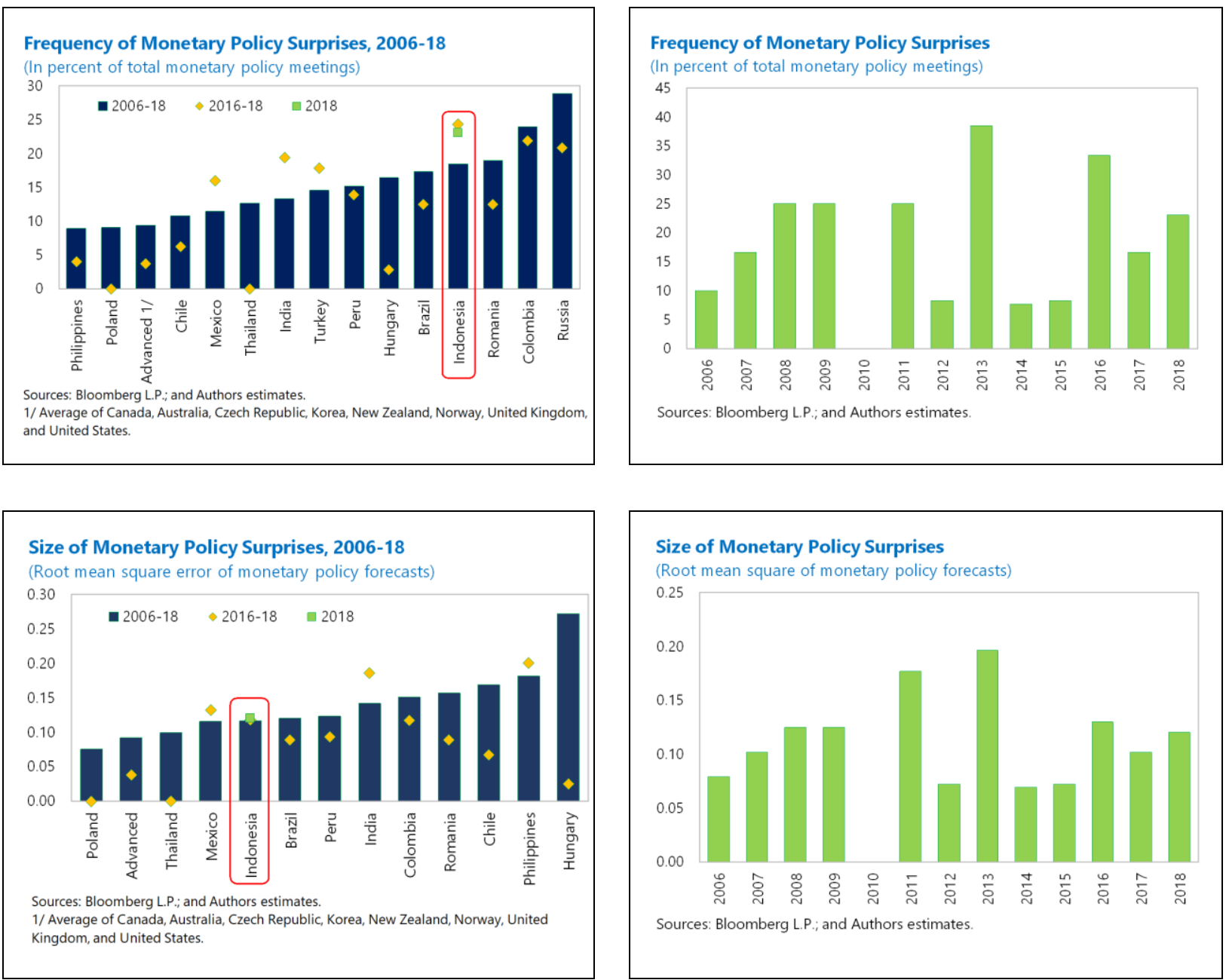


\section{APPEndix IV. Decomposition OF Median SurPrises ANd AVERAge SurPrises}

\section{Decomposition of Surprises}

(Frequency number and percent, median)

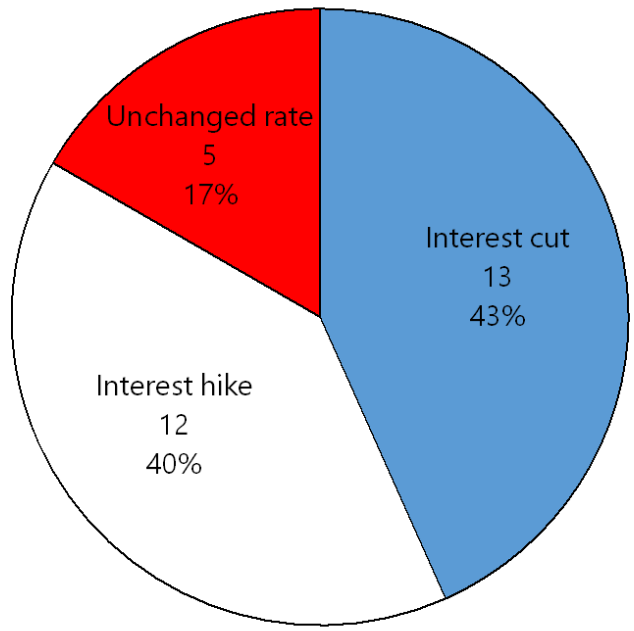

Sources: Bloomberg L.P.; and Authors estimates.

\section{Decomposition of Surprises}

(Frequency number and percent, average)

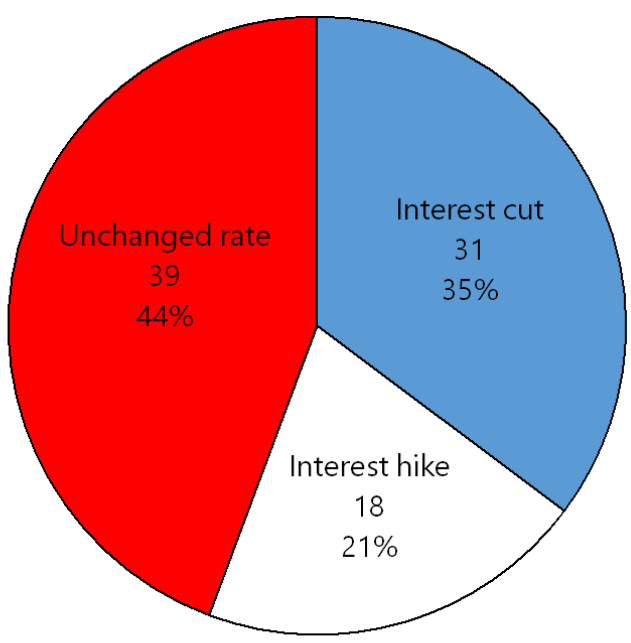

Sources: Bloomberg L.P.; and Authors estimates. 


\section{ApPendix V. Impact of Monetary Policy SurPrises and Publications}

Table V. 1. Impact Monetary Policy Surprise and Anticipation 1/

\begin{tabular}{|c|c|c|c|c|c|c|c|c|c|}
\hline \multirow[b]{2}{*}{ Variables } & \multirow{2}{*}{$\begin{array}{l}\text { Overnight } \\
\text { Interbank }\end{array}$} & \multicolumn{4}{|c|}{ Interbank } & \multicolumn{3}{|c|}{ Government Bond Yield } & \multirow{2}{*}{$\begin{array}{c}\text { Exchange } \\
\text { Rate }\end{array}$} \\
\hline & & 1-week & 2-week & 3-week & 1-month & 1-year & 5-year & 10-year & \\
\hline Unanticipated & $\begin{array}{l}1.369^{* * *} \\
(0.357)\end{array}$ & $\begin{array}{l}1.000^{* * * k} \\
(0.19)\end{array}$ & $\begin{array}{l}1.195 * * * \\
(0.252)\end{array}$ & $\begin{array}{l}0.469 * * * \\
(0.17)\end{array}$ & $\begin{array}{l}0.540^{* * *} \\
(0.21)\end{array}$ & $\begin{array}{r}0.285 \\
(0.175)\end{array}$ & $\begin{array}{r}0.133 \\
(0.113)\end{array}$ & $\begin{array}{l}-0.008 \\
(0.096)\end{array}$ & $\begin{array}{l}112.883 \\
(75.787)\end{array}$ \\
\hline Anticipated & $\begin{array}{r}0.442 \\
(0.376)\end{array}$ & $\begin{array}{r}0.334 \\
(0.224)\end{array}$ & $\begin{array}{l}0.505 * \\
(0.258)\end{array}$ & $\begin{array}{r}0.203 \\
(0.221)\end{array}$ & $\begin{array}{r}0.231 \\
(0.167)\end{array}$ & $\begin{array}{l}-0.014 \\
(0.087)\end{array}$ & $\begin{array}{r}0.001 \\
(0.057)\end{array}$ & $\begin{array}{l}-0.115 \\
(0.058)\end{array}$ & $\begin{array}{r}0.946 \\
(20.736)\end{array}$ \\
\hline Constant & $\begin{array}{l}-0.014 \\
(0.039)\end{array}$ & $\begin{array}{r}0.003 \\
(0.016)\end{array}$ & $\begin{array}{r}0.014 \\
(0.019)\end{array}$ & $\begin{array}{r}0.005 \\
(0.016)\end{array}$ & $\begin{array}{r}0.010 \\
(0.025)\end{array}$ & $\begin{array}{l}-0.003 \\
(0.015)\end{array}$ & $\begin{array}{r}-0.003 \\
(0.01)\end{array}$ & $\begin{array}{l}-0.006 \\
(0.048)\end{array}$ & $\begin{array}{r}-2.198 \\
(5.42)\end{array}$ \\
\hline Observations & 135 & 135 & 135 & 135 & 135 & 126 & 138 & 141 & 141 \\
\hline R-squared & 0.079 & 0.213 & 0.246 & 0.075 & 0.050 & 0.029 & 0.013 & 0.001 & 0.027 \\
\hline
\end{tabular}

1/ Standard errors in parentheses ${ }^{* * *} p<0.01,{ }^{* *} p<0.05,{ }^{*} p<0.1$

Table V.2. Impact of Press Release on Market Rates 1/

\begin{tabular}{|c|c|c|c|c|c|c|c|c|}
\hline \multirow[b]{2}{*}{ Variables } & \multicolumn{4}{|c|}{ Interbank } & \multicolumn{3}{|c|}{ Government Bond Yield } & \multirow{2}{*}{$\begin{array}{c}\text { Exchange } \\
\text { Rate }\end{array}$} \\
\hline & 1-week & 2-week & 3-week & 1-month & 1-year & 5-year & 10-year & \\
\hline \multirow[t]{2}{*}{ Overnight } & $0.759 * * *$ & $0.327 * *$ & 0.063 & -0.211 & -0.055 & 0.009 & -0.071 & 47.169 \\
\hline & $(0.1)$ & $(0.144)$ & $(0.081)$ & $(0.313)$ & $(0.091)$ & $(0.089)$ & $(0.083)$ & (34.571) \\
\hline \multirow[t]{2}{*}{ Surprise dummy } & $-0.046 * *$ & -0.051 & 0.028 & -0.005 & 0.029 & 0.012 & 0.008 & -14.485 \\
\hline & $(0.018)$ & $(0.034)$ & $(0.032)$ & $(0.05)$ & $(0.03)$ & $(0.019)$ & $(0.014)$ & $(10.925)$ \\
\hline \multirow[t]{2}{*}{ Surprise dummy ${ }^{\star}$ Overnight } & $-0.439 * k *$ & -0.095 & -0.087 & 0.304 & -0.094 & -0.023 & 0.077 & -51.566 \\
\hline & $(0.106)$ & $(0.178)$ & $(0.078)$ & $(0.315)$ & $(0.141)$ & $(0.09)$ & $(0.084)$ & $(35.952)$ \\
\hline \multirow[t]{2}{*}{ Unanticipated } & $1.008^{* k *}$ & $1.201^{* * *}$ & $0.466^{* * * k}$ & $0.539 * *$ & 0.213 & 0.159 & -0.015 & 134.627 * \\
\hline & $(0.147)$ & $(0.246)$ & $(0.171)$ & $(0.212)$ & (0.159) & $(0.117)$ & $(0.09)$ & (81.048) \\
\hline \multirow[t]{2}{*}{ Anticipated } & $0.301 * *$ & $0.479 * *$ & 0.214 & 0.237 & -0.049 & 0.009 * & -0.056 * & -7.623 \\
\hline & $(0.141)$ & $(0.208)$ & $(0.227)$ & $(0.152)$ & $(0.112)$ & $(0.061)$ & $(0.028)$ & $(22.487)$ \\
\hline \multirow[t]{2}{*}{ Constant } & $0.028^{* * *}$ & $0.042^{* *}$ & -0.010 & 0.013 & -0.010 & $-0.008^{* * *}$ & 0.037 & 5.984 \\
\hline & $(0.008)$ & $(0.017)$ & $(0.017)$ & $(0.037)$ & $(0.023)$ & $(0.013)$ & $(0.01)$ & $(5.707)$ \\
\hline Observations & 135 & 135 & 135 & 135 & 122 & 135 & 135 & 135 \\
\hline R-squared & 0.725 & 0.422 & 0.083 & 0.078 & 0.046 & 0.026 & 0.026 & 0.052 \\
\hline
\end{tabular}

1/ Standard errors in parentheses: ${ }^{* * *} p<0.01,{ }^{* *} p<0.05,{ }^{*} p<0.1$ 
Table V.3. Impact of Monetary Policy Reports on Market Rates 1/

\begin{tabular}{|c|c|c|c|c|c|c|c|c|}
\hline \multirow[b]{2}{*}{ Variables } & \multicolumn{4}{|c|}{ Interbank } & \multicolumn{3}{|c|}{ Bond Yield } & \multirow[b]{2}{*}{$\begin{array}{l}\text { Exchange } \\
\text { Rate }\end{array}$} \\
\hline & 1 week & 2 week & 3 week & 1 month & 1 year & 5 year & 10 year & \\
\hline \multirow[t]{2}{*}{ Overnight Interbank Rate (ON) } & $0.313^{* * *}$ & $0.245 * * *$ & $0.031 * *$ & 0.013 * & -0.003 & 0.001 & -0.002 & 1.793 \\
\hline & 0.030 & 0.041 & 0.015 & 0.007 & 0.004 & 0.002 & 0.003 & 1.430 \\
\hline \multirow[t]{2}{*}{ Monetary Policy Report Dummy (MPR_D) } & 0.000 & -0.005 & 0.019 & 0.046 & -0.006 & -0.002 & 0.016 & -17.1 ** \\
\hline & 0.024 & 0.027 & 0.016 & 0.032 & 0.014 & 0.007 & 0.019 & 8.023 \\
\hline \multirow[t]{2}{*}{ ON*MPR_D } & 0.019 & -0.063 & -0.003 & -0.011 & 0.040 & 0.002 & 0.013 & -4.781 \\
\hline & 0.074 & 0.082 & 0.029 & 0.035 & 0.039 & 0.007 & 0.013 & 7.207 \\
\hline \multirow[t]{2}{*}{ Constant } & 0.000 & 0.000 & -0.001 & -0.002 & 0.000 & 0.000 & 0.019 *** & 5.242 ** \\
\hline & 0.006 & 0.007 & 0.006 & 0.007 & 0.004 & 0.002 & 0.004 & 2.173 \\
\hline Observations & 2,703 & 2,703 & 2,703 & 2,703 & 2,390 & 2,692 & 2,703 & 2,703 \\
\hline R-squared & 0.461 & 0.284 & 0.009 & 0.002 & 0.000 & 0.000 & 0.000 & 0.001 \\
\hline
\end{tabular}

1/ Standard errors in parentheses: ${ }^{* *} p<0.01,{ }^{* *} p<0.05,{ }^{*} p<0.1$.

Table V.4. Impact of Press Release and Monetary Policy Report-An Alternative Approach 1/

\begin{tabular}{|c|c|c|c|c|c|c|c|c|c|}
\hline \multirow[b]{2}{*}{ Variables } & \multirow{2}{*}{$\begin{array}{l}\text { Overnight } \\
\text { Interbank }\end{array}$} & \multicolumn{4}{|c|}{ Interbank } & \multicolumn{3}{|c|}{ Government Bond Yield } & \multirow{2}{*}{$\begin{array}{c}\text { Exchange } \\
\text { Rate }\end{array}$} \\
\hline & & 1-week & 2-week & 3-week & 1-month & 1-year & 5-year & 10-year & \\
\hline \multirow[t]{2}{*}{ Press Release Dummy } & -0.051 & -0.005 & 0.010 & -0.014 & 0.008 & 0.000 & 0.011 & $-0.117 * *$ & -5.434 \\
\hline & $(0.052)$ & $(0.02)$ & $(0.022)$ & $(0.018)$ & $(0.023)$ & $(0.013)$ & $(0.008)$ & $(0.05)$ & $(6.642)$ \\
\hline \multirow[t]{2}{*}{ MPR Release Dummy } & 0.002 & 0.028 & 0.006 & $-0.029 *$ & 0.015 & -0.021 * & $-0.017 * * \star$ & -0.012 & -8.120 \\
\hline & $(0.076)$ & $(0.032)$ & $(0.027)$ & $(0.017)$ & $(0.027)$ & $(0.011)$ & $(0.005)$ & $(0.09)$ & $(6.662)$ \\
\hline \multirow[t]{2}{*}{ Policy Rate Change } & -0.401 & -0.262 ** & -0.197 & -0.131 & -0.097 & 0.033 & -0.002 & 0.061 & -18.329 \\
\hline & $(0.233)$ & $(0.127)$ & $(0.164)$ & $(0.143)$ & $(0.114)$ & $(0.049)$ & $(0.037)$ & $(0.048)$ & (29.573) \\
\hline \multirow[t]{2}{*}{ Macroeconomic releases dummy } & -0.042 & -0.035 ** & $-0.050 * * *$ & -0.007 & $-0.056 * * *$ & -0.004 & -0.004 & -0.011 & -7.000 \\
\hline & $(0.038)$ & $(0.015)$ & $(0.013)$ & $(0.016)$ & $(0.012)$ & $(0.01)$ & $(0.005)$ & $(0.056)$ & $(6.43)$ \\
\hline \multirow[t]{2}{*}{ Constant } & $0.253^{* \star *}$ & 0.142 *** & $0.150^{* * *}$ & 0.081 *** & $0.158^{* * *}$ & $0.095^{* * *}$ & $0.062 * * *$ & 0.230 *** & $70.726 * * *$ \\
\hline & $(0.018)$ & $(0.008)$ & $(0.008)$ & $(0.006)$ & $(0.007)$ & $(0.004)$ & $(0.002)$ & $(0.022)$ & $(5.299)$ \\
\hline Observations & 2,703 & 2,703 & 2,703 & 2,703 & 2,703 & 2,506 & 2,840 & 2,965 & 2,966 \\
\hline R-squared & 0.0009 & 0.0023 & 0.0027 & 0.0011 & 0.0040 & 0.0008 & 0.0017 & 0.0006 & 0.0002 \\
\hline
\end{tabular}

1/ Standard errors in parentheses: ${ }^{* * *} p<0.01,{ }^{* *} p<0.05,{ }^{*} p<0.1$ 


\section{APPENDIX VI. DATA SOURCE}

\begin{tabular}{|c|c|c|}
\hline Variables & Description & Source \\
\hline Unanticipated Policy & $\begin{array}{l}\text { The difference between BI's rate decision (it) and } \\
\text { analysts' anticipated rate (Et-1it) }\end{array}$ & $\begin{array}{l}\text { Bloomberg L.P. (Bank } \\
\text { Indonesia Reference Interest } \\
\text { Rate Index) }\end{array}$ \\
\hline Anticipated Policy & $\begin{array}{l}\text { The difference between analysts' anticipated rate } \\
\text { (Et-1it) and actual BI's rate }\left(i_{t-1}\right)\end{array}$ & $\begin{array}{l}\text { Bloomberg (Bank Indonesia } \\
\text { Reference Interest Rate } \\
\text { Index) }\end{array}$ \\
\hline Press Release Dummy & $\begin{array}{l}\text { Dummy variable for Monetary Policy Press } \\
\text { Release date (if any press release } 1 \text {, otherwise } 0 \text { ). }\end{array}$ & Bank Indonesia \\
\hline MPR Release Dummy & $\begin{array}{l}\text { Dummy variable for Monetary Policy Report } \\
\text { Release date (if any MPR release 1, otherwise } 0 \text { ). }\end{array}$ & Bank Indonesia \\
\hline $\begin{array}{l}\text { Policy Rate Change } \\
\text { Dummy }\end{array}$ & $\begin{array}{l}\text { Dummy variable for Monetary Policy Rate (BI } \\
\text { rate) Change (if any rate changes } 1 \text {, otherwise } 0 \text { ). }\end{array}$ & Bank Indonesia \\
\hline $\begin{array}{l}\text { Macroeconomic Release } \\
\text { Dummy }\end{array}$ & $\begin{array}{l}\text { Release dates for major macroeconomic variables } \\
\text { of Indonesia - GDP, CPI, The Nikkei Indonesia } \\
\text { Manufacturing Purchasing Managers' Index and } \\
\text { Current Account balance (if any release 1, } \\
\text { otherwise } 0 \text { ). }\end{array}$ & Bloomberg L.P. \\
\hline Policy Rate Change & $\begin{array}{l}\text { Change in Monetary Policy Rate (BI rate) from } \\
\text { previous day }\end{array}$ & Bank Indonesia \\
\hline Overnight Interbank & $\begin{array}{l}\text { Change in actual overnight interbank money } \\
\text { market rate from previous day }\end{array}$ & Bank Indonesia \\
\hline 1-week Interbank & $\begin{array}{l}\text { Change in actual 1-week interbank money market } \\
\text { rate from previous day }\end{array}$ & Bank Indonesia \\
\hline 2-week Interbank & $\begin{array}{l}\text { Change in actual 2-week interbank money market } \\
\text { rate from previous day }\end{array}$ & Bank Indonesia \\
\hline 3-week Interbank & $\begin{array}{l}\text { Change in actual 3-week interbank money market } \\
\text { rate from previous day }\end{array}$ & Bank Indonesia \\
\hline 1-month Interbank & $\begin{array}{l}\text { Change in actual 1-month interbank money market } \\
\text { rate from previous day }\end{array}$ & Bank Indonesia \\
\hline $\begin{array}{l}\text { 1-year Government Bond } \\
\text { Yield }\end{array}$ & $\begin{array}{l}\text { Change in 1-year government bond yields from } \\
\text { previous day }\end{array}$ & $\begin{array}{l}\text { Bloomberg L.P. (GIDN1YR } \\
\text { index) }\end{array}$ \\
\hline $\begin{array}{l}5 \text {-year Government Bond } \\
\text { Yield }\end{array}$ & $\begin{array}{l}\text { Change in 5-year government bond yields from } \\
\text { previous day }\end{array}$ & $\begin{array}{l}\text { Bloomberg L.P. (GIDN5YR } \\
\text { Index) }\end{array}$ \\
\hline $\begin{array}{l}\text { 10-year Government } \\
\text { Bond Yield }\end{array}$ & $\begin{array}{l}\text { Change in 10-year government bond yields from } \\
\text { previous day }\end{array}$ & $\begin{array}{l}\text { Bloomberg L.P. } \\
\text { (GIDN10YR Index) }\end{array}$ \\
\hline Exchange Rate & $\begin{array}{l}\text { Change in Indonesian spot rupiah per U.S. dollar } \\
\text { form previous day }\end{array}$ & Bloomberg \\
\hline FedRate & $\begin{array}{l}\text { Change in Federal Funds Effective rate from } \\
\text { previous day }\end{array}$ & Haver Analytics \\
\hline $\begin{array}{l}\text { 1-month money market } \\
\text { rate }\end{array}$ & $\begin{array}{l}\text { Change in 1-month U.S. Treasury Bill Yield from } \\
\text { previous day }\end{array}$ & Haver Analytics \\
\hline $\begin{array}{l}\text { 10-year government bond } \\
\text { yield }\end{array}$ & $\begin{array}{l}\text { Change in 10-year U.S. Treasury Bond Yield from } \\
\text { previous day }\end{array}$ & Haver Analytics \\
\hline EMBI spread & $\begin{array}{l}\text { Change in JPMorgan Emerging Market Bond } \\
\text { Global (EMBIG) Index Sovereign Spread for } \\
\text { Indonesia }\end{array}$ & $\begin{array}{l}\text { Bloomberg L.P. (JPSSGIDO } \\
\text { Index) }\end{array}$ \\
\hline $\mathrm{CDS}$ & $\begin{array}{l}\text { Change in Indonesia 5-Year Sovereign Credit } \\
\text { Default Swaps }\end{array}$ & Bloomberg L.P. \\
\hline
\end{tabular}




\section{REFERENCES}

Adrian, Tobias, Douglas Laxton, and Maurice Obstfeld, 2018, "An Overview of Inflation-Forecast Targeting," Chapter 1 in Advancing the Frontiers of Monetary Policy (Washington: International Monetary Fund).

Andrea, Pescatori, 2018, "Central Bank Communication and Monetary Policy Surprises in Chile," IMF Working Paper No. 18/156 (Washington: International Monetary Fund).

Bernoth, Kirsten, and Jürgen von Hagen, 2004, "The Euribor Futures Market: Efficiency and the Impact of ECB Policy Announcements," International Finance, Vol. 7, Issue 1, pp. 1-24.

Blattner, T., M. Catenaro, M. Ehrmann, R. Strauch, and J. Turunen, 2008, The Predictability of Monetary Policy, ECB Occasional Paper No. 83 (Frankfurt: European Central Bank).

Blinder, Alan, 1998, Central Banking in Theory and Practice (Cambridge, Massachusetts: MIT Press).

Blinder, Alan S., and others, 2008, "Central Bank Communication and Monetary Policy: A Survey of Theory and Evidence,” Journal of Economic Literature, Vol. 46, Issue 4, pp. 910-45.

Bulir, A., M. Cihak, D. Jansen, 2014, "Does the Clarity of Inflation Reports Affect Volatility in Financial Markets?,” IMF Working Paper No. 14/175 (Washington: International Monetary Fund).

Connolly, Ellis, and Marion Kohler, 2004, "News and Interest Rate Expectations: A Study of Six Central Banks," Reserve Bank of Australia Research Discussion Paper No. 2004-10 (Sydney: Reserve Bank of Australia).

Demiralp, Selma, and Oscar Jorda, 2002, "The Announcement Effect: Evidence from Open Market Desk Data," Federal Reserve Bank of New York Economic Policy Review, Vol. 8, pp. 29-48.

Dincer, N., and B. Eichengreen, 2007, "Central Bank Transparency: Where, Why and with What Effects?,” NBER Working Paper No. 13003, March (Cambridge: National Bureau of Economic Research).

Dincer, N., and B. Eichengreen, 2014, "Central Bank Transparency and Independence; Updates and New Measures," International Journal of Central Banking, Vol. 10, Issue 1, pp. 189-259. 
, 2007, "The Timing of Central Bank Communication," European Journal of Political Economy, Vol. 23, Issue 1, pp. 124-145.

Fracasso A., H. Genberg, C. Wyplosz, 2003, How do Central Banks Write? An Evaluation of Inflation Reports by Inflation Targeting Central Banks, Geneva Reports on the World Economy Special Report 2 (Geneva: International Center for Monetary and Banking Studies and Centre for Economic Policy Research).

Geerats, Petra, 2002, “Central Bank Transparency,” The Economic Journal, Vol. 112, Issue 483, pp 532-65.

Gürkaynak, R.S., B. Sack, E. Swanson, 2005, "The Sensitivity of Long-Term Interest Rates to Economic News: Evidence and Implications for Macroeconomic Models," The American Economic Review, Vol. 95, No. 1 (March).

Hernandez-Murillo, R., H. G. Shell, 2014, "The Rising Complexity of the FOMC Statement," Federal Reserve Bank of St. Louis Economic Research, Economic Synopses, No. 23.

International Monetary Fund, 2019, Indonesia-Staff Report for the 2019 Article IV Consultation, IMF Country Report No. 19/250 (Washington). ,2018, "Credibility, Communication, and Monetary Policy Procyclicality in Latin America," Chapter 3 in Regional Economic Outlook, April 2018, Western Hemisphere Department: Seizing the Momentum, April (Washington).

Kohn, Donald L., and Brian Sack, 2004, "Central Bank Talk: Does It Matter and Why?," FEDS Working Paper No. 2003-55 (Washington: Board of Governors of the Federal Reserve System).

M. McMahon., A. Schipke., Xiang Li, 2018, “China's Monetary Policy Communication: Frameworks, Impact, and Recommendations," IMF Working Paper No. 18/244 (Washington: International Monetary Fund).

Poole, William, and Robert H. Rasche, 2003, "The Impact of Changes in FOMC Disclosure Practices on the Transparency of Monetary Policy: Are Markets and the FOMC Better "Synched"?," Federal Reserve Bank of St. Louis Review, Vol. 85, Issue 1, pp. 1-10.

Rozkrut, Marek, Krzysztof Rybiński, Lucyna Sztaba, and Radoslaw Szwaja, 2007, "Quest for Central Bank Communication: Does It Pay to Be 'Talkative'?," European Journal of Political Economy, Vol. 23, pp 176-206. 
Swanson, Eric T, 2006, "Federal Reserve Transparency and Financial Market Forecasts of Short-Term Interest Rates," Journal of Money, Credit, and Banking, Vol. 38, Issue 3, pp. 791-819.

Unsal, D. F., C. Papageorgiou, and H. Garbers, 2019, "Monetary Policy Frameworks: An Index and New Evidence," IMF Working Paper (forthcoming). 